\title{
Protective Effect of Soybean against Hepatocarcinogenesis Induced by DL-Ethionine
}

\author{
Fatma Aiad", Basiouny El-Gamal ${ }^{\dagger} *$, Jehan Al-Meer ${ }^{\S}$, Zinab El-Kerdasy ${ }^{\dagger}$, \\ Nadia Zakhary ${ }^{\dagger}$ and Abdelbaset El-Aaser ${ }^{\dagger}$ \\ 'Department of Cancer Biology, National Cancer Institute, Cairo University, Egypt \\ ¿Department of Biochemistry, Faculty of Science, Alexandria University, Egypt \\ ${ }^{\S}$ Department of Chemistry, Faculty of Science, Qatar University, P.O. Box 2713 Doha, State of Qatar
}

Received 7 July 2003, Accepted 8 January 2004

There has been increasing interest in the value of using soybean to delay or reduce the tumor incidence. This study was undertaken to investigate the possible protective effects of soybean against hepatocarcinogenesis induced by DLethionine. Accordingly, we measured biochemical changes occurring in serum and liver of rats treated with DL-ethionine in the presence or absence of soybean. Male albino rats were fed a control diet containing the hepatocarcinogen, DLethionine, or the control diet plus soybean $30 \%$, or the control diet plus soybean plus DL-ethionine $\mathbf{0 . 2 5 \%}$ for three months and then returned to a control diet for up to nine months. Rats fed a control diet plus DL-ethionine showed a gradual decrease in liver DNA, RNA, total protein, and liver weight and enzyme activites of liver transaminases (GOT and GPT) and alkaline phosphatase over the 7-month study period. This was followed by a large increase in the liver parameters at the end of the $9^{\text {th }}$ month, except for 5'-nucleotidase and glucose-6-phosphatase that showed a large decrease. On the other hand, a gradual increase in the serum enzyme activities of GOT, GPT, 5nucleotidase, alkaline phosphatase, and in the albumin/globulin (A/G) ratio is observed in the group of rats fed a control diet plus DL-ethionine compared to the control group over 8 months, and this was followed by a large increase in all serum parameters studied at nine-months. The administration of $30 \%$ soybean to the rat diet in addition to DL-ethionine maintained all parameters studied at near control values until the end of the $9^{\text {th }}$ month. This study suggests that soybean has a protective effect against the hepatocarcinogenesis induced by DL-ethionine.

Keywords: DL-ethionine, Hepatocarcinogenesis, Soybean protection

*To whom correspondence should be addressed.

Tel: 02-03-428-7576, Fax: 02-03-391-1794

E-mail: basiouny_el_gamal@hotmail.com

\section{Introduction}

During the past two decades, attention has been focused on the possible role of soybeans, which contain trypsin inhibitors, isoflavones, and phytic acid (Anderson and Wolf, 1995), on reducing or delaying the incidence of many tumors in experimental animals (Roll et al., 1980; Corasanti et al., 1982; Barnes et al., 1990; Messina and Messina, 1991; Webb et al., 1992; Anderson and Wolf, 1995; Thiagarajan et al., 1998; Appelt and Reicks, 1999; Messina, 1999; Onozawa et al., 1999; Lamartiniere, 2000; Su et al., 2000; Zaizen et al., 2000).

It has been previously demonstrated by our group that soybeans have a protective effect against the hepatocarcinogenesis induced by para-dimethylaminoazobenzene (El-Aaser et al., 1986) and 7,12-dimethylbenz(a)anthracene in rats (El-Aaser et al., 1994) or by the nitrosamine precursors dibutylamine and nitrate in mice (Mokhtar et al., 1988; Moharram et al., 1989; Zakhary et al., 1989). In addition, soybean isoflavone extract has been reported to suppress the early promotion of hepatocarcinogenesis induced by phenobarbital in rats (Lee $e t$ al., 1995).

This study was planned to investigate the possible protective role of soybeans against the effect of DL-ethionine, which is a potent hepatocarcinogen (Lenzi et al., 1991; Novikoff et al., 1991; Tsujiuchi et al., 1995; Allen and Poirier, 1997; Hacker et al., 1998; Akhurst et al., 2001; Croager et al., 2002). This was attempted by studying some of the biochemical changes that occur in liver and serum, and histopathologic changes in the liver of rats treated with DLethionine in the presence or absence of soybean.

\section{Materials and Methods}

Three hundred and sixty adult male Swiss albino rats, aged between 4-5 weeks and weighing from 50 to 60 grams, were divided into the 
following groups:

1. Rats in the control group were maintained on a control diet, composed of $20 \%$ casein, $15 \%$ corn oil, $55 \%$ cornstarch, $5 \%$ salt mixture, and $5 \%$ vitaminized starch. Drinking water was supplied ad libitum.

2. Rats in DL-ethionine group were given a diet containing the hepatocarcinogen, DL-ethionine, at a concentration of $0.25 \%$ and maintained on the same diet used for the control group.

3. The rats in soybean group were maintained on the control diet containing $30 \%$ autoclaved ground soybean. This was performed at $107^{\circ} \mathrm{C}$ for 15 minutes.

4. The rats in DL-ethionine + soybean group were maintained on a diet containing DL-ethionine under the conditions mentioned for the DL-ethionine group. Autoclaved soybean was added to their diet at a concentration of $30 \%$.

Animals were given DL-ethionine for three months only, while soybean was given throughout the 9 month period of study. Ten rats from each group were sacrificed monthly over a period of nine months. Blood samples were taken and serum collected. Livers were removed, washed, dried and weighed. A portion of the liver was homogenized in distilled water at a ratio of $1: 20(\mathrm{w} / \mathrm{v})$. Another portion was fixed in $10 \%$ formalin, embedded in paraffin, sectioned, stained with hematoxylin and eosin, and subjected to microscopic examination. Serum and liver homogenates were subjected to the following biochemical investigations: DNA and RNA were extracted from liver homogenate, as described previously (Melmed et al., 1976) and quantified as described by Radwan (1980) and Mejbaum (1939), respectively. Total protein was determined in serum and liver homogenate using the method of Lowry et al. (1951). Serum albumin level was determined according to the method described by Spencer and Price (Spencer and Price, 1977). Serum globulin level was obtained by determining the difference between serum total protein and serum albumin, then calculating the albumin/globulin ratio. Alkaline phosphatase and 5'nucleotidase activities were determined in both serum and liver homogenate according to the method previously described (ElAaser and El-Merzabani, 1975). Transaminases (GOT and GPT) activities were determined in both serum and liver homogenate (Reitman and Frankel, 1957), and glucose-6-phosphatase was determined in liver homogenate (De Duve et al., 1955).

\section{Results}

The results of the soybean group for all parameters studied were similar to those of the control group, therefore, we selected the soybean group as the control group, and all results were then calculated as percent change with respect to the soybean group.

Figure 1 shows the content of RNA and DNA in liver for the different groups of rats over the nine month study period. For rats in the DL-ethionine group, RNA and DNA contents showed a gradual decrease until over seven months, a slight increase after 8 months, and a large increase at the end of nine months. For rats treated with DL-ethionine + soybean, values of liver RNA and DNA contents were near control values over the whole study period.

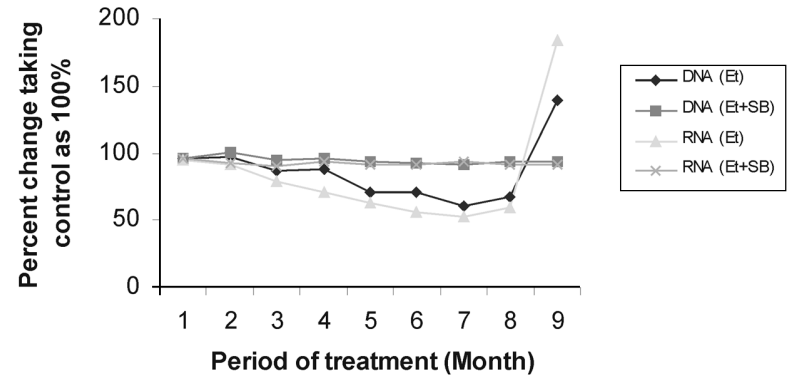

Fig. 1. DNA and RNA contents in the liver homogenates of rats during hepatocarcino-genesis in the presence and absence of soybean.

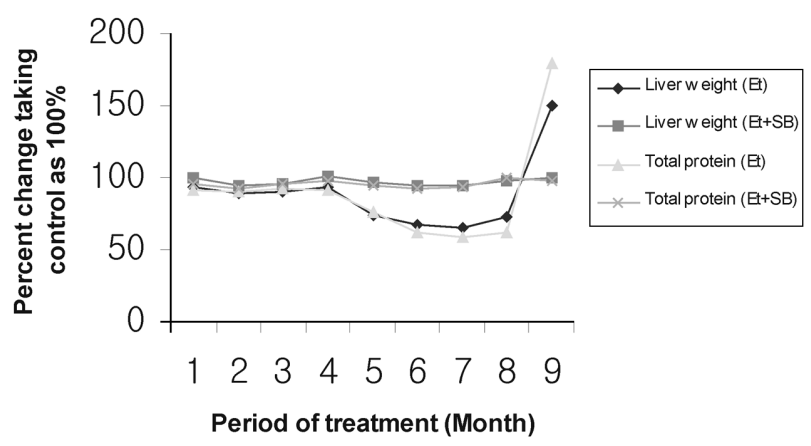

Fig. 2. Total protein content in liver homogenates and the liver weights of rats during hepatocarcinogenesis in the presence and absence of soybean.

Figure 2 shows the liver weights and liver total protein content of the different treated groups studied. For rats in the DL-ethionine group, liver weight, and total protein content showed a gradual decrease over seven months, a slight increase after eight months, and a large increase after nine months. However, rats fed soybean in addition to DLethionine had values near to those of the control group over the whole study period.

Figure 3 demonstrates a gradual reduction in liver GOT activity until the end of eight months followed by a large increase after nine months. On the other hand, serum GOT activity showed a gradual increase throughout the 1-8 months period followed by a large increase after nine months. However, the DL-ethionine + soybean group had liver and serum GOT activity values that were similar to those of the soybean control group.

Figure 4 shows a gradual reduction in liver GPT activity for eight full months followed by a large increase after nine months in the DL-ethionine group. On the other hand, serum GPT activity showed a gradual increase throughout the 1-8 months period followed by a large increase after nine months. However, rats fed soybean + DL-ethionine had liver and serum GPT activities close to those of the control group.

Figure 5 demonstrates a gradual and sharp reduction in liver 5 '-nucleotidase activity in the DL-ethionine group throughout the 9 month study period, whereas serum enzyme activity was 


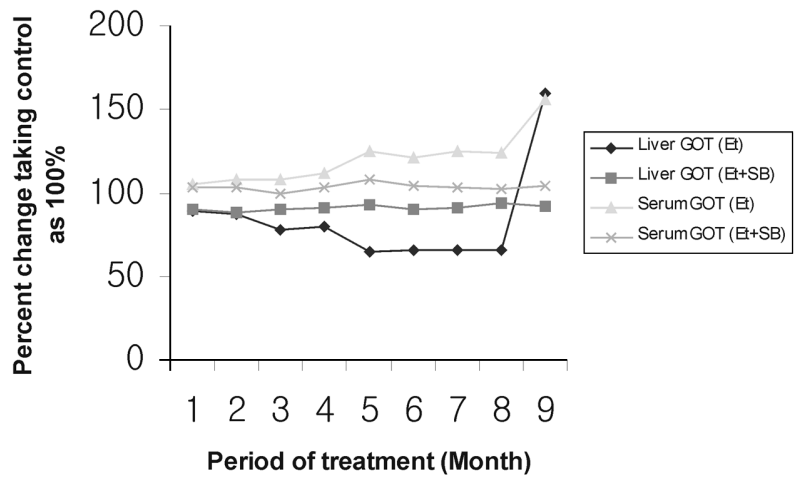

Fig. 3. GOT activity in liver homogenates and in the serum of rats during hepatocarcino-genesis in the presence and absence of soybean.

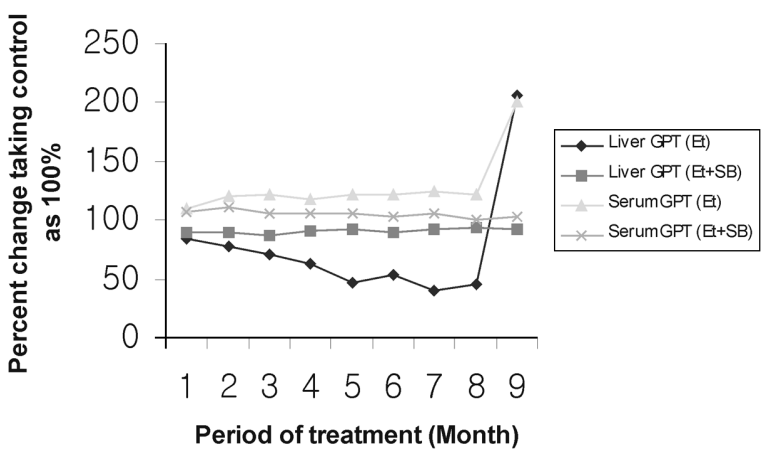

Fig. 4. GPT activity in liver homogenates and in the serum of rats during hepatocarcino-genesis in the presence and absence of soybean.

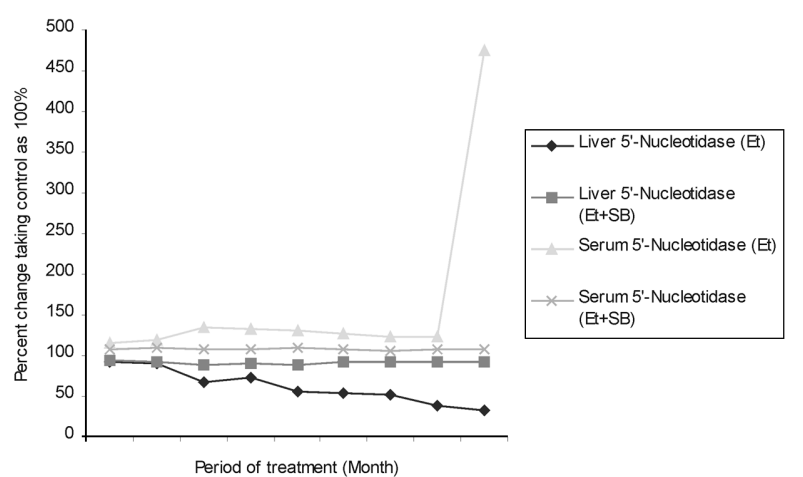

Fig. 5. 5'-Nucleotidase activity in liver homogenates and in the serum of rats during hepatocarcinogenesis in the presence and absence of soybean.

slightly higher than the control values over the 1-8 months period, this increased markedly after nine months. However, both liver and serum activities of 5'-nucleotidase were near to those of the control group for rats in the DL-ethionine + soybean group after nine months.

Figure 6 shows that liver alkaline phosphatase activity decreased gradually in the DL-ethionine group for eight months and then markedly increased after nine months,

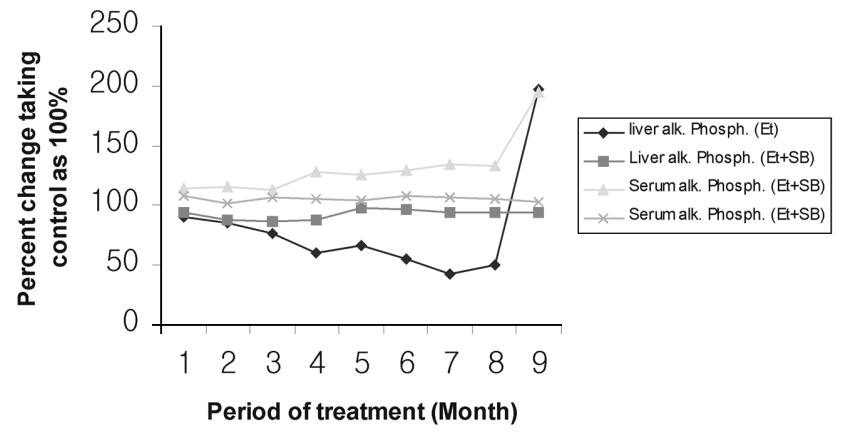

Fig. 6. Alkaline phosphatase activity in liver homogenates and in the serum of rats during hepatocarcinogenesis in the presence and absence of soybean.

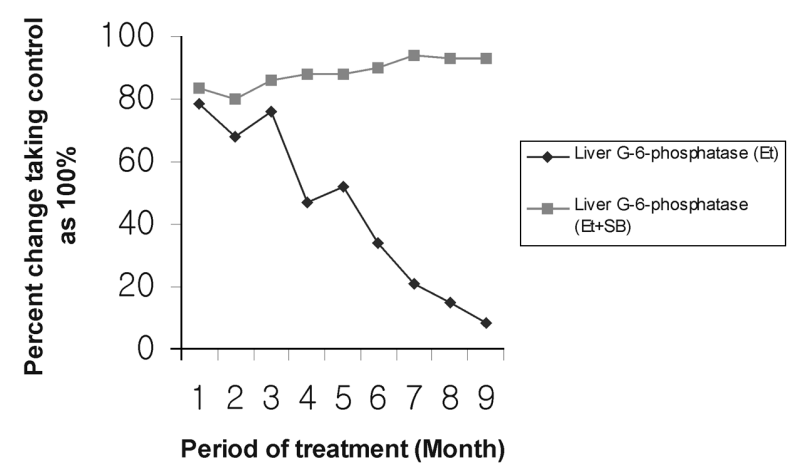

Fig. 7. Glucose-6-phosphatase activity in the liver homogenates of rats during hepatocarcinogenesis in the presence and absence of soybean.

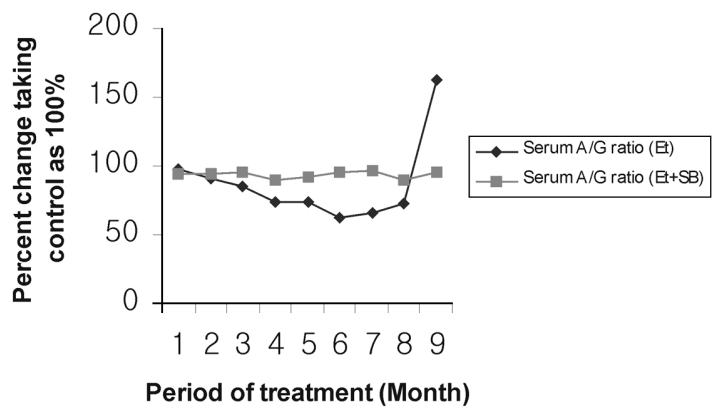

Fig. 8. Serum $A / G$ ratio of rats during hepatocarcinogenesis in the presence and absence of soybean.

whereas its activity in serum increased gradually over the 1-8 months period and then this too showed a large increase after nine months. However, both liver and serum activities of alkaline phosphatase were near the control values for DLethionine + soybean animals throughout the study period.

Figure 7 shows gradual and sharp reduction in liver glucose-6-phosphatase in the DL-ethionine group over 1-8 months, which reached a minimum after nine months. Rats in the DL-ethionine + soybean group showed gradually increasing liver glucose-6-phosphatase activity, which reached the control value during the 5-9 month stage. 
Table 1. Pathological changes in rats fed hepatocarcinogen, (DL-ethionine), with and without soybean ${ }^{a}$

\begin{tabular}{lcccc}
\hline & Control & Soybean & Ethionine & Ethionine+ soybean \\
\hline Architecture & & & & \\
1-Liver Cells & 92 & 88 & -- & -- \\
-Normal & 8 & 12 & 26.1 & 22.4 \\
-Fatty degeneration & - & - & 29.3 & 25.3 \\
-Hydropic degeneration & - & - & 38.0 & -- \\
-Foci of necrosis & - & - & 22.1 & -- \\
2-Early nuclear changes & - & - & \\
3-Hepatoma & - & & \\
\hline
\end{tabular}

a: Results are expressed as percentage of incidence.

Figure 8 shows a gradual reduction in the serum $A / G$ ratio over the 1-8 months period in the DL-ethionine group followed by a large increase after nine months. However, rats in the DL-ethionine+soybean group had values close to those of the control group at nine months.

Table 1 represents pathological changes in rats fed hepatocarcinogen with or without soybean after nine months of treatment. High incidences of fatty and hydropic degeneration were observed in groups receiving DL-ethionine either alone or in addition to soybean. Foci of necrosis, early nuclear changes, and hepatoma were observed only in the group receiving DL-ethionine.

\section{Discussion}

This study was undertaken to investigate the possible protective role of soybean against DL-ethionine-induced hepatocarcinogenesis.

Feeding rats a control diet containing DL-ethionine, produced many biochemical changes in the liver and serum. Throughout the 8 month study period, a gradual decrease in RNA, DNA, total protein in liver, and in liver weight and enzyme activities was observed. Meanwhile, enzyme activities in serum showed a gradual increase. This might be due to the acute toxicity and destructive effect of the hepatocarcinogen accompanied by reduced nucleic acid synthesis. This acutely toxic effect may result in the death of hepatocytes and the release of intracellular enzymes into the circulation, thereby showing a rapid and significant increase of these enzymes in serum.

When the carcinogenic response is initiated, it is accompanied by the proliferation of both parenchymal and non-parenchymal cells (DeLamirande, 1964), nucleic acids recovery and increased cellular activity (Miller, 1970). In the present study, a histopathological examination revealed liver cell destruction, necrosis, degeneration and in the 9th month hepatoma appeared. The appearance of hepatoma was identified by elevated RNA, DNA and total protein in liver, and by an increased liver weight, which may have been due to a chemical interaction between the carcinogen and RNA,
DNA and proteins. It is known that cancerous cells synthesize more protein than normal cells.

The increased activity of liver transaminases (GOT and GPT) with induced hepatoma might be due to altered protein metabolism and increased enzyme biosynthesis. Liver alkaline phosphatase activity elevation indicates tumor progression (Pugh and Goldfrab, 1978; Hacker et al., 1998), increased DNA synthesis and cell replication (Emmelot and Bos, 1971). This might indicate that alkaline phosphatase partially maintains optimal levels of mononucleotides that participate in DNA synthesis (Emmelot and Bos, 1971).

The reduced activity of liver 5'-nucleotidase with induced hepatoma, found in the present study, might be due to the inhibitory action of the carcinogen on the rate of enzyme synthesis (El-Aaser, 1965; Karnovsky et al., 1975), or to specific structural changes in the membranes of malignant cells and a subsequent reduction in enzyme activity (Inbar et al., 1977; Raz et al., 1978).

Reduced glucose-6-phosphatase activity is a characteristic feature of liver toxicity or malignant transformation in hepatic cells. The liver glucose-6-phosphatase activity reduction in the presence of induced hepatoma, revealed in the present study, may be due the proliferation of the so-called "oval" liver cells induced by the hepatocarcinogen, which precedes or accompanies the development of hepatoma (Lenzi et al., 1991; Hacker et al., 1992; Hacker et al., 1998). These proliferated oval cells nay be transformed into hepatocytes, and cytochemical studies have revealed that these cells are poorly developed with a negative or very small degree of glucose-6-phosphatase (Hacker et al., 1992). Histochemical studies by our group (El-Aaser et al., 1986) have shown that glucose-6-phosphatase and 5'-nucleotidase activities are down-regulated in the liver cells of rats fed a diet containing the hepatocarcinogen, p-dimethylaminoazobenzene. However, normal activities were observed in rats fed a diet containing soybean in addition to the hepatocarcinogen. The increased activity of transaminases and alkaline phosphatase in serum of rats with DL-ethionine-induced hepatoma might be due to the increased biosynthesis of these enzymes and/or their liberation into circulation because of liver cell destruction caused by the hepatocarcinogen. 
The high serum 5'-nucleotidase activity revealed by induced hepatoma in the present study might be due to the shedding of plasma membrane vesicles associated with malignant liver cells (Moharram et al., 1989). These vesicles have a specific lipid and protein composition and high 5'-nucleotidase activity (Novikoff et al., 1991).

Feeding rats a soybean diet containing DL-ethionine resulted in RNA, DNA, and total protein in liver, and liver weight and liver enzyme activities close to those of the control group throughout the study period. Also, serum enzymatic activities and the $\mathrm{A} / \mathrm{G}$ ratio showed values near to those of the control group over the 9 months study period in this group.

Histopathological examination of the group receiving DLethionine in addition to soybean showed fatty and hydropic degeneration. However, the group maintained on DLethionine alone showed many pathological changes including fatty and hydropic degeneration, foci of necrosis, early nuclear changes and hepatoma. Similar histopathological results were obtained by our group for rats treated with a different hepatocarcinogen (para-dimethylaminoazobenzene) either alone or in addition to soybean (El-Aaser et al., 1986).

The mechanism of soybean protection against cancer induced by chemical carcinogens might be achieved through various ways. The hepatocarcinogen might be absorbed to soybean fibers, thus has little chance of reaching the target cells in the liver tissue. It has been reported that diets rich in fiber lower the incidence of chemically induced tumors (Reddy et al., 1983). In addition, soybean protection might be attributed to trypsin inhibitors that are abundantly present in soybean and have a blocking effect on the malignant transformation induced by chemical carcinogens (Roll et al., 1980; Corasanti et al., 1982; Barnes et al., 1990; Kennedy, 1995). Akl and El-Kaabi (1992) reported that rats treated with heated soybean and p-dimethylaminoazobenzene developed pathological changes including hepatoma. Since heating soybean destroys its trypsin inhibitors, this might indicate that trypsin inhibitors may have a role in a cancer protection mechanism. Although the soybean used in our study was autoclaved to denature protease inhibitors, it is possible that residual amounts of these inhibitors might have been present in the soybean fed to the rats. The protective effect of soybean might also be due to its content of isoflavones, like genistein, which are believed to have a potential role in reducing tumor incidence (Hacker et al., 1998). These isoflavones have been reported to reduce the risk of breast cancer (Messina, 1999; Lamartiniere, 2000) and urinary tract cancer (Su et al., 2000) in animal studies. Lee et al. (1995) reported that soybean isoflavones may have an anticarcinogenic effect by suppressing the early stages of hepatocarcinogenesis induced by diethylnitrosamine.

In conclusion, the present study demonstrates that soybean has a protective effect against the hepatocarcinogenesis induced by DL-ethionine.

\section{References}

Akhurst, B., Croager, E. J., Farley-Roche, C. A., Ong, J. K., Dumble, M. L., Knight, B. and Yeoh, G. C. (2001) A modified choline-deficient, ethionine-supplemented diet protocol effectively induces oval cells in mouse liver. Hepatology 34, 519-522.

Akl, S. M. and El-Kaabi, N. A. (1992) Effect of soybean feeding on experimental carcinogenesis. J. Egypt. Nat. Center Inst. 5, 443-471.

Allen, P. T. and Poirier, L. A. (1997) Suppression by Phenobarbital of ethionine-induced hepatocellular carcinoma formation and hepatic S-adenosylethionine levels, Carcinogenesis 18, 1103-1107.

Anderson, R. L. and Wolf, W. J. (1995) Compositional changes in trypsin inhibitors, phytic acid, saponins and isoflavones related to soybean processing. J. Nutr. 125, 581S-588S.

Appelt, L. C. and Reicks, M. M. (1999) Soy induces phase II enzymes but does not inhibit dimethylbenz[a]anthraceneinduced carcinogenesis in female rats. J. Nutr. 129, 1820-1826.

Barnes, S., Grubbs, C., Setchell, K. D. and Carlson, J. (1990) Soybeans inhibit mammary tumors in models of breast cancer. Prog. Clin. Biol. Res. 347, 239-253.

Corasanti, J. B., Hobika, G. H. and Markus, G. (1982) Interference with dimethylhydrazine induction of colon tumors in mice by aminocaproic acid. Science 216, 1020-1028.

Croager, E. J., Smith, P. G. and Yeoh, G. C. (2002) Ethanol interactions with a choline-deficient, ethionine-supplemented feeding regime potentiate preneoplastic cellular alterations in rat liver. Carcinogenesis 23, 1685-1693.

De Duve, C., Pressman, B. C., Gianetto, O. R., Wahianx, R. and Applemans, F. (1955) Tissue fractionation studies, intracellular distribution pattern of enzymes in rat liver tissue. Biochem. $J$. 60, 604-613.

De Lamirande, G. (1964) Protein bound dye and purine catabolizing enzymes in parenchymal and non-parenchymal cells of rats fed 4-dimethylamine- azobenzene (DAB). Cancer Res. 24, 742-750.

El-Aaser, A. A. (1965) Nucleotidases and ribonucleases in liver and liver tumors. $\mathrm{PhD}$ thesis, London University.

El-Aaser, A. A. and El-Merzabani, M. M. (1975) Simultaneous determination of 5-nucleotidase and alkaline phosphatase activities in serum. Z. Klin. Chem. Klin. Biochem. 13, 453-459.

El-Aaser, A. A., Ibrahim, H. A., Abdeen, A. M. and AKL, S. A. (1986) Effect of soybean feeding on Experimental carcinogenesis. 1. Hepatocarcinogenesis by para-dimethyl aminoazobenzene (DAB) in rats fed soybean: Histopathological and histochemical studies. J. Egypt. Natl. Cancer Inst. 2, 443453.

El-Aaser, A. A., Zakhary, N. I., El-Guindy, S. M., Hafeiz, A. A., Mokhtar, N. (1994) Effect of soybean, vicia faba, and vitamin C on the carcinogenicity of DMBA. Nutr. Cance. 22, 195-200.

Emmelot, P. and Bos, C. T. (1971) Studies on plasma membrane. XV. A sex difference in alkaline phosphatase activities of plasma membrane isolated from rat liver. Biochem. Biophys. Acta 249, 293-300.

Hacker, H. J., Steinberg, P. and Bannasch, P. (1998) Pyruvate kinaseisoenzyme shift from L-type to M2-type is a late event 
in hepatocarcinogenesis induced in rats by a choline-deficient/ DL-ethionine-supplemented diet. Carcinogenesis 19, 99-107.

Hacker, H. J., Steinberger, P., Toshkov, I., Oesch, F., Bannasch, P. (1992) Persistence of the cholangiocellular and hepatocellular lesions observed in rats fed a choline-deficient/DL-ethioninesupplemented diet. Carcinogenesis 13, 271-276.

Inbar, M., Yuli, I. and Raz, A. (1977) Contact mediated changes in the fluidity of membrane lipids in normal and malignant transformed mammalian fibroblasts. Expl. Cell. Res. 105, 325335.

Karnovsky, M. L., Lazdins, J., Drath, D. B. and Harper, H. (1975) Biochemical characteristics of activated macrophages. Ann. N. Y. Acad. Sci. 256, 266-275.

Kennedy, A. R. (1995) The evidence for soybean products as cancer preventive agents. J. Nutr. 125, 733S-743S.

Lamartiniere, C. A. (2000) Protection against breast cancer with genistein: a component of soy. Am. J. Clin. Nutr. 71, 1705S$1707 \mathrm{~S}$.

Lee, K. W., Wang, H. J., Murphy, P. A. and Hendrich, S. (1995) Soybean isoflavone extract suppresses early but not later promotion of hepatocarcinogenesis by Phenobarbital in female rat liver. Nutr. Cancer 24, 267-278.

Lenzi, R., Liu, M. H., Lenzen, R., Han, T., Alpini, G. and Tavoloni, N. (1991) Distribution of glucose-6-phosphatase activity in normal, hyperplastic, and preneoplastic rat liver. Virchows. Arch. B. Cell. Pathol. Incl. Mol. Pathol. 61, 279-287.

Lowry, O.H., Rosenbrough, S.N. and Randell, S.R. (1951) Protein measurement with the Folin phenol reagent. J. Biol. Chem., 193, 265-275.

Melmed, R. M., El-Aaser, A. A. and Holt, S. J. (1976) Hypertrophy and hyperplasia of the neonatal rat exocrine pancreas induced by orally administered soybean trypsin inhibitor. Bioch. Biophys. Acta 321, 280-288.

Mejbaum, W. (1939) Uber die bestimung kleiner pentosemengen, insbesondere in derivaten der adenylasaure. Z. Physiol. Chem. 268, 117-121.

Messina, M. J. (1999) Legumes and soybeans: overview of their nutritional profiles and health effects. Am. J. Clin. Nutr. 70, 439S-450S.

Messina, M. and Messina, V. (1991) Increasing use of soyfoods and their potential role in cancer prevention. J. Am. Diet. Assoc. 91, 836-840.

Miller, J. A. (1970) Carcinogenesis by biochemicals. An overview CHA. Clowes memorial lectures. Cancer Res. 30, 559-570.

Moharram, N. Z., El-Aaser, A. A., Badr El-Din, N. K. and Ibrahim, H. A. (1989) Effect of soybean on experimental carcinogenesis. IV. Phosphatases in mice liver, histochemical study. Proc. Zool. Soc. A.R. Egypt 17, 211-226.

Mokhtar, N. M., El-Aaser, A. A., El-Bolkainy, M. N., Ibrahim, H. A., Badr El-Din, N. and Moharram, N. Z. (1988) Effect of soybean feeding on experimental carcinogenesis. IIICarcinogenicity of nitrite and dibutylamine in mice: A histopathological study. Eur. J. Cancer Clin. Oncol. 24, 403411.

Novikoff, P. M., Ikeda, T., Hixon, D. C. and Yam, A. (1991) Characterization of and interactions between bile ductule cells and hepatocytes in early stages of rat hepatocarcinogenesis induced by DL-ethionine..Am. J. Pathol. 139, 1351-1368.

Onozawa, M., Kawamori, T., Baba, M., Fukuda, K., Toda, T., Sato, H., Ohtani, M., Akaza, H., Sugimura, T. and Wakabayashi, K. (1999) Effects of a soybean isoflavone mixture on carcinogenesis in prostate and seminal vesicles of F344 rats. Jpn. J. Cancer Res. 90, 393-398.

Pugh, T. and Goldfrab, S. (1978) Quantitative histochemical and autoradiographic studies of hepatocarcinogenesis in rats fed 2acetylamino fluorine followed by Phenobarbital. Cancer Res. 38, 4450-4457.

Radwan, A. F. (1980) Studies on the effect of soybean feeding on the biochemistry of liver during carcinogenesis. PhD thesis Fac. Med., Cairo University, Egypt.

Raz, A., Collard, J. G. and Inbar, M. (1978) Decrease in 5nucleotidase activity in malignant transformed and normal stimulated cells. Cancer Res. 38, 1258-1262.

Reddy, B. C., Maeaura, Y. and Wayman, M. (1983) Effect of dietary corn barn and autohydrolyzed lignin on 2,3-dimethyl-4aminobiphenyl induced intestinal carcinogenesis in male F344 rats. J. Natl. Cancer Inst. 71, 419-426.

Reitman, S. and Frankel, S. (1957) A colorimetric method for the determination of serum glutamic oxaloacetic acid and glutamic pyruvic transaminases. Am. J. Pathol. 28, 56-63.

Rroll, W., Wiesner, R., Shellabarge, C. T., Holtzman, S. and Stone, J. P. (1980) Soybean diet lowers breast tumor incidence in irradiated rats. Carcinogenesis 1, 469-475.

Spencer, K. and Price, C. P. (1977) Influence of reagent quality and reaction conditions on the determination of serum albumin by the bromocresol green dye-binding method. Ann. Clin. Biochem. 14, 105-115.

Su, S. J., Yeh, T. M., Lei, H. Y. and Chow, N. H. (2000) The potential of soybean foods as a chemoprevention approach for human urinary tract cancer. Clin. Cancer Res. 6, 230-236.

Thiagarajan, D. G., Beenink, M. R., Bourquin, L. D. and Kavas, F. A. (1998) Prevention of precancerous colonic lesions in rats by soy flakes, soy flour, genistein, and calcium. Am. J. Clin. Nutr. 68, 1394S-1399S.

Tsujiuchi, T., Kobayashi, E., Nakae, D., Mizumoto, Y., Andoh, N., Kitada, H., Ohashi, K., Fukuda, T., Kido, A. and Tsutsumi, M. (1995) Prevention by methionine of enhancement of hepatocarcinogenesis by coadministration of a choline-deficient L-amino acid-defined diet and ethionine, Jpn. J. Cancer Res. 86, 1136-1142.

Webb, T. E., Stromberg, P. C., Abu-Issa, H. and Curley, R. W. Jr., Moeschberger, M. (1992) Effect of dietary soybean and licorice on the male F344 rat: an integrated study of some parameters relevant to cancer chemoprevention. Nutr. Cancer 18, 215-230.

Zaizen, Y., Higuchi, Y., Matsuo, N., Shirabe, K., Tokuda, H. and Takeshita, M. (2000) Antitumor effects of soybean hypocotyls and soybeans on the mammary tumor induction by N-methyln-nitrosourea in F344 rats. Anticancer Res. 20, 1439-1444.

Zakhary, N. I., Badr El-Din, N., El-Aaser, A. A., Ibrahim, H. A. and Moharram, N. Z. (1989) Effect of soybean feeding and vitamin $\mathrm{C}$ on experimental carcinogenesis. 5. Biochemical changes in the liver of albino mice induced by feeding nitrite and dibutylamine. J. Egypt. Natl. Cancer Inst. 4, 186-189. 